\title{
住まいと音 一生活騒音一
}

\section{1. 建築工法の変化と居住者の意識}

万国博, 山陽新幹線建設, 超高層ビルに象徵される 建設ラッシュのさなか, 建築基準法として初めての音 響的記述をむつ法30条の 2 「長屋又は共同住宅の界壁 は，政令で定める技術的基準に従って，遮音上有効な 構造としなければならない」が制定されたのは，1970 年のことであった。そして，翌71年には，騒音規制法 に環境基準が盛り込まれ，72年には日本学術会議から 声明「騒音問題の重要性を訴える」屯出ている.

いわゆる経済の高度成長にともなう住宅の大量供給 期における，かかる法律もしくは声明の出現は，住宅 居住者の生活を守るうえから，まことに時宜を得たも のであった，そしてその成立の背景には，「建築の工 法の変化」と「自らの生活環境を守万うとする国民の 意識の高まり」があった，と考えられる。

つまり, 当時の建築界では, 建物の高層化と軽量化, そして工期の短縮を目ざす新工法への転換が積極的に 進められていた，共同住宅においても鉄骨フレーム造 による気泡コンクリート版工法, プレキャストコンク リート版工法が増えていったが，これら建物はその構 造的軽さのゆえに音・振動を伝え易いものであった． また，住戸間の界壁も湿式（RC現場打ちなど）加ら 乾式（石こうボード壁など）への移行にともなって壁 面が励振し易くなり，遮音性を保持し難い壁構造が多 くなったのである。

一方, 経済の高度成長期は, 各種の公害問題に対し て国民の関心が高まり，自らの居住環境を守ろうとす る意識がめばえた時期でもあった。 とくに，共同住宅 に打ける騒音は, 四六時中いう起うるか力判らない多種 多様の音だけに，居住者に「被害者」としての意識を 植え付け,「生活騒音 (community noise)」なる新

\footnotetext{
*(䀿日本建築総合試験所環境試験室長
}

Tsuyoshi TOKURA
しい概念をかもし出した。

換言すれば,「生活騒音」は，住宅の大量供給と集 約化によって顕在化した, 生活にともなう種々雑多な 音，と定義できる。

\section{2. 生活騒音防止への取組み}

「建築基準法30条の $2 」$ の制定は，その後の住宅建 設に大きなインパクトを与えた．

建設業界およびその関連業界においては, 乾式工法 による「軽くて遮音性のある壁」への開発研究が始ま り，以後10年間（1971 1980末）に67件の乾式壁が 「遮音構造」として建設省より認定されている。

また, 日本建築学会, 日本音響学会などでも建築 基準法遮音規準值 $25 \mathrm{~dB}(125 \mathrm{~Hz}), 40 \mathrm{~dB}(500 \mathrm{~Hz})$, $50 \mathrm{~dB}(2,000 \mathrm{~Hz})$ の達成を目標にした測定例の報告, あるいは研究論文が增加した. 各種のアンケート調査, 実態調查など, 音響性能を含めた居住性の研究, 各種 建築物における遮音性能に係わる論議 屯盛んとなった。 そして，それらの成果が現在も使用されている「建築 物の遮音性能基準之設計指針」（日本建築学会, 1979） へとつながる。

遮音性能を含む「工業化住宅の性能認定制度」（建 設省，1973），JIS A1417「建築物の現場における音 のレベル差の測定方法」(1974)，JIS A4708「防音サッ シ」(1976), JIS A1419「建築物のしゃ音等級」(1979) など，居住者の立場を意識した音響性能に関する評価 基準，もしくは測定方法の出現も上記と同一の流れの 中にとらえることができる.

このような状況のなかで，1976年には実務的音響工 学者によって日本騒音制抑工学会が設立された。「音 響問題を実務レベルで」が同工学会設立の趣旨である が,「生活騒音」に対して同会会誌「騒音制抑」は, 《特集・住環境の騒音》（Vol.6 No.2，1982）で幅 広い研究分野からのアプローチの必要性を示唆してい 
る，参考までに，同特集に含まれる各夕イトルを以下 に示そう。これまで個々に続けられていた調査もしく は研究を一堂に会したという点で，同特集は「生活騒 音」に対する新しい局面を開いた.

・生活環境の騒音把握の考え方

- 環境騒音問題の国際的動向

- 個人の騒音暴露と音環境

・騒音と社会調査

・集合住宅における生活騒音の評価方法

・空気流（風）のゆらぎと超低周波音

・集合住宅における音響特性の調査

・集合住宅戸境壁の遮音性能

・住環境評価における聴覚と視覚

\section{3. 生活騷音の実態}

日常生活を営むうえで発生し, 他室で聴取される音 には, 電話のベル, 話し声, テレビの音などに代表さ れる「空気伝搬音」と, 子供の跳びはね, 便所・浴室 の給排水など，建物に生じた振動が他室で音となる 「固体伝搬音」に大別される．ステレオ，ピアノなど は，双方の性質をむつ，といってもよい．

このような到来音が,「生活騒音」となるか否かは， 一律に決まるものではなく，それを聴取する人の精神 的・肉体的な状態, さらには近隣との親密度などに支 配される.

たとえば，近年の片廊下式集合住宅では，各階ごと が，自治会・管理組合の 1 単位となっている場合が多 い，階上，階下の住戸は，独立した単位であり，普段 からのつき合いは無い. 顔む知らないから, 苦情を伝 えるには多大の勇気が要る。うっ積したストレスは, 耳の感度をさらに鋭敏にすることになる，事実，筆者 の勤務先にもしばしば上階からの床衝撃音に関するク レームが寄せられるが，上下住戸間に近隣関係の無い 場合が多く，一旦こじれた感情は，ますますエスカレー トする傾向にある.

このような状況のもとで，いくつかの行政体では， 生活騒音に関して, 住民に対するアンケート調查, あ るいは居住環境の実態を調査している. 本稿では, そ れらのなかから内容の豊富な東京都「生活騒音防止対 策実態調査」をむとに，その一部を抜すいして生活騒 音の実態をご紹介したい. 1985年春から 3 年間を費や した同調査の内容は, 次のようになっている.

（1）住民生活行動意識調査（実施期間 : '87. 9～10)

（2）現地環境調查 （" : '87.9 10）
（3）区市の苦情処理実態調查（＂：＇85.4～'87. 8)

（4）生活騒音防止協定事例調查（"：'87 秋)

（5）出張販売業者等実態調査 （"：８７）

(6) メーカー・業界団体等ヒアリング調查

( " : '87.10 '88.2)

なお，上記(1)の「住民生活行動意識調査」は判り難 い表現であるが，居住者の「世帯構成・建物構造・自 家用車の有無・近所づき合いの程度・定住意識」など 生活騒音の要因を分析すべく実施された約40項目にわ たるアンケート調査である。本稿に抜粋した図ー 1 お よび表 1 は, 同調査による集計結果である.

また, 図一 2 は都内23区および26市の生活騒音苦情 処理空口が受付けた896件の苦情をもとに実施された 上記(3)の調査結果である.この調査では,「近隣との つき合いの程度」も調査項目に含まれているが，それ によれば,「ほとんどない」62.4\%，「挨拶・立話程度」 $27.7 \%$ ，「親密なつきあい」0.7\%, 残りは「不明」と なっている.

図一 1 から, 戸建住宅における上位 3 位は,

(1) 自動車・オートバイの空ぶかし音 $30.7 \%$

(2) 話し声・騒ぎ声・泣き声 18.5\%

(3) ペットの泣き声 18.3\%

一方，集合住宅におけるそれは，

(1) 跳びはねる音・物を落とす音 $38.1 \%$

(2) 自動車・オートバイの空ぶかし音 38.0\%

(3) 話し声・騒ぎ声・泣き声 18.3\%

であり,「生活騒音」の内容は，まず戸建・集合にお ける住居の型式, 周囲の環境によって, また乗用車の 普及など, 生活様式の変化によっても異なる. とくに 集合住宅では，「跳びはねる・物を落とす」など行衝 撃性の指摘が高いが，同アンケート調查で実施された 要因分析（表１）によれば，集合住宅における床衝撃 音への苦情は,「近所づきあい程度」が大きな要因と なっている.これは法的規制の困難さと同時に集合住 宅におけるコミュニティづくりの大切さを示すすので あり，建築設計者としても，かつての「階段室型式中 層共同住宅」がそうであったように，「挨拶を交す」 程度のつきあいができる工夫を建築計画に反映させる 必要があろう。

なお，先述のごとく図ー 2 は都の苦情空口に寄せら れた件数であるが，「掃除機・子供の飛び歩きや足音」 など床衝撃音に関する苦情は少なく, 図ー 1 のアンケー トによる苦情の指摘率とそれを行動に移す行為との間 には，かなりのギャップがある。これは，集合住宅に 


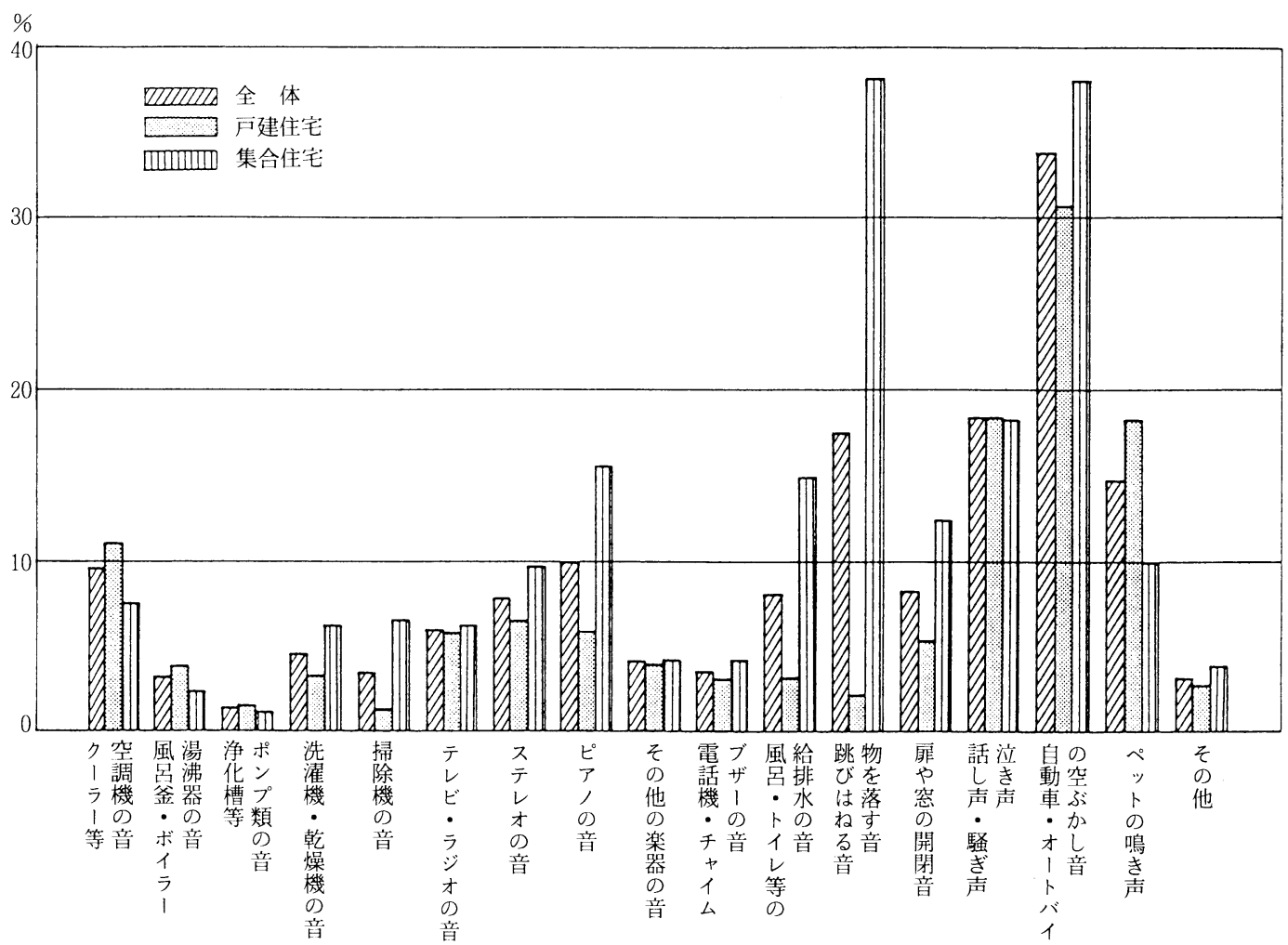

図－1 アンケート調查による生活騒音の被害発生状況（1987東京都）

表 1 発生源別被害発生要因の分析結果

(1988東京都)

\begin{tabular}{|c|c|c|c|}
\hline \multicolumn{2}{|r|}{ 騒 音 源 } & 被害発生要因 & 徵 \\
\hline $\begin{array}{l}\text { 家 } \\
\text { 庭 } \\
\text { 教 } \\
\text { 師 }\end{array}$ & クーラー等空調機 & $\begin{array}{l}\text { +クーラー普及度 } \\
\text { + 用途地域混在度 } \\
\text { +周辺密集度 } \\
\text { +建物老朽度 }\end{array}$ & \\
\hline \multirow{2}{*}{$\begin{array}{l}\text { 䪭 } \\
\text { 機 } \\
\text { 器 }\end{array}$} & テレビ・ラジオ & $\begin{array}{l}\text { - 定住意識 } \\
\text { + 周辺密集度 }\end{array}$ & \\
\hline & $ヒ^{0} \quad ア$ & +ピアノ普及率 & 集合住宅 \\
\hline \multirow{4}{*}{$\begin{array}{l}\text { 生 } \\
\text { 活 } \\
\text { 行 } \\
\text { 動 } \\
\text { に } \\
\text { 伴 } \\
\text { う } \\
\text { 音 }\end{array}$} & $\begin{array}{l}\text { 風呂・トイレ等の } \\
\text { 給 排 水 }\end{array}$ & $\begin{array}{l}\text { 一近所づきあい程度 } \\
\text { －居住年数 }\end{array}$ & 集合住宅 \\
\hline & $\begin{array}{l}\text { 跳びは衫る音・物 } \\
\text { を落とす音 }\end{array}$ & 一近所づきあい程度 & 集合住宅 \\
\hline & 屝や空の開閉音 & $\begin{array}{l}\text { - 近所づきあい程度 } \\
\text { +建物老朽度 } \\
\text { - 定住意識 } \\
\text { + 周辺密集度 }\end{array}$ & 鉄骨系住宅 \\
\hline & $\begin{array}{l}\text { 話し声・騒ぎ声・ } \\
\text { 泣 き } \\
\end{array}$ & $\begin{array}{l}\text { －近所づきあい程度 } \\
\text { －定住意識 }\end{array}$ & 鉄骨系住宅 \\
\hline \multirow{2}{*}{\begin{tabular}{l|} 
そ \\
の \\
他
\end{tabular}} & $\begin{array}{l}\text { 自動車・オートバ } \\
\text { イの空ぶかし }\end{array}$ & $\begin{array}{l}\text { －自動車・オートバイ } \\
\text { 普及率 }\end{array}$ & \\
\hline & ペットの鳴き声 & $\begin{array}{l}\text { 一近所づきあい程度 } \\
+ \text { ペット保有率 } \\
\text { 一建築面積 }\end{array}$ & 戸建住宅 \\
\hline
\end{tabular}

注）＋は被害発生促進要因, 一は被害発生抑制要因として 㗢くことを示す.
おける居住者の大部分が「我慢をしている」ことを示 すむのに他ならない。

もし将来, 界床の床衝撃音遮断性能について何らか の法的規制を設けるとすれば，その一法として「我慢 している」住戸上階の床構造の実態を知ることにより， 㦿に要求される最低限の水準を設定できるように思う. いかがなあのであろうか.

\section{4. 住まいと音}

生活騒音について，いくつかのことを述べた。しか し現在, 生活騒音は生活様式の多様化や居住環境の高 密度化にともなって増加しつつある. 遅くまで営業す るガソリンスタンド，コンビニエンスストアからの騒 音が生活騒音であるかどうかは別にしてあ, 現代人の 生活は夜型に移行しており,「大学生・短大生の同居 家庭, 自由業の家庭」では, 自らが被害者であると同 時に加害者になっていることを前記の調查報告書は示 している.

また, さきの図ー 2 では, 都に申し出のあった生活 騒音896件に対して，「掃除機，子供の飛び歩きや足音」 など床衝撃音に関するものはわずか16件（1.8\%）で あった.しかしその後, 事情は相当に変化した. 


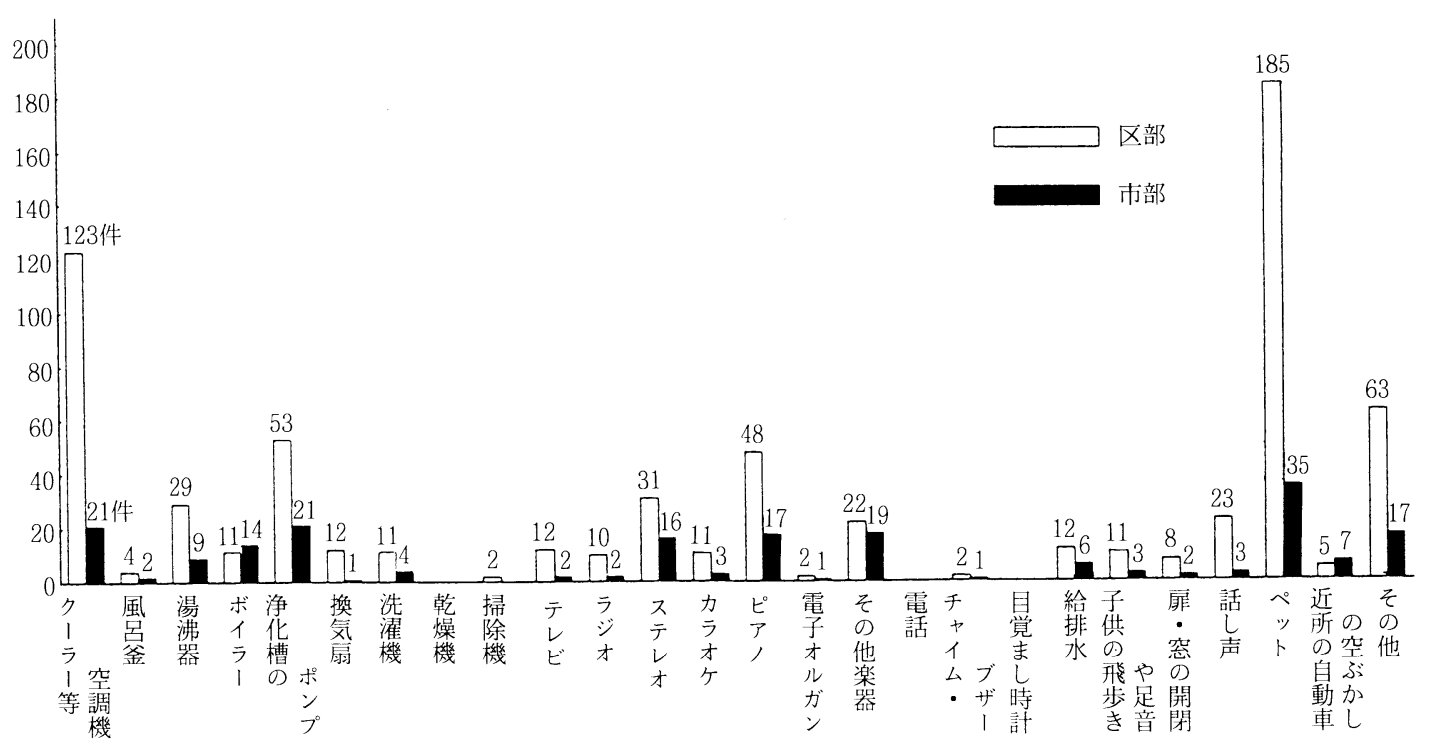

図－２＼cjkstart苦情相談空口に寄せられた発生源別苦情件数（1985～1987東京都）

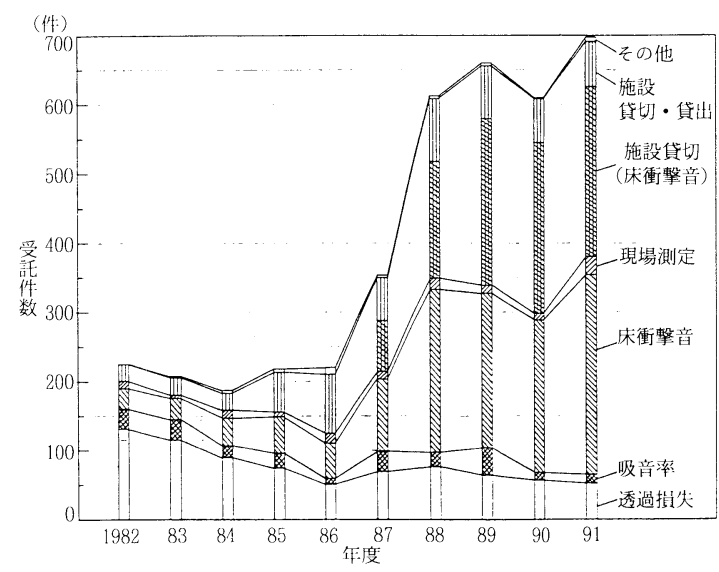

図一 3 最近10年間に受託した音響試 験（日本建築総合試験所）

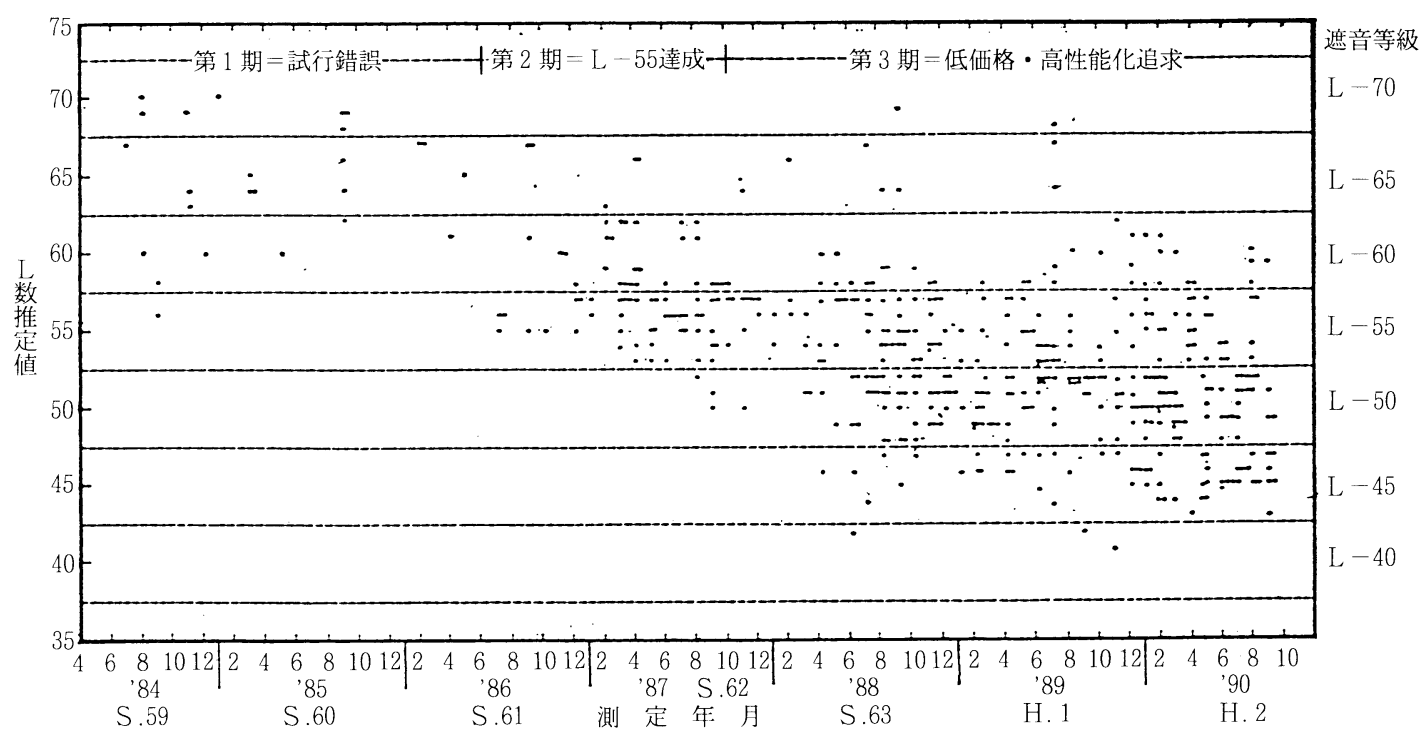

図－4 直張り木質フローリングの床衝撃音遮断性能の変化（日本建築総合試験所） 
「ダニ問題」や「清潔感」あるいは「内装の高級志向」 によって木質床が好まれるようになり，階下への音は 増大した，そしてその結果が，昨今の木質フローリン グに係わる訴訟，あるいはマンションにおける管理規 約の見直し，もしくは木質床禁止へとつながっている.

ここ数年の間, 高性能木質床への開発は活発であり, (財)日本建築総合試験所の受託状況にもこれがよく表わ れている (前頁図一 3 参照). そして, その床衝撃音 遮断性能む図－4（前頁）のように年々向上しつつあ るが，木は所詮木である。カーペットを貼り替えて， これと同厚, しかも同等の床衝撃音遮断性能を木質床 に期待するのは無理というあのであろう。

木質床の性能確保を目指して, 1990年には床材メ一 カー・施工店を中核とする日本防音床材工業会（事務
局：大阪）が発足した。また，本年（1992）4月には， 集合住宅における各種の問題を解決するために日本マ ンション学会（事務局：京都, 大阪）が設立された。 床衝撃音は今や, 集合住宅がかかえる課題の最たるも のである. 後者の当面の活動として, 床衝撃音問題が 取り上げられるのは, まず間違いのないところだ。公 的試験機関の一員として，また消費者の一人として， 「住まいと音」でこれからもしばらく悩みそうである。

\section{参 考 資 料}

1) 東京都環境保全局編; 生活騒音防止対策実態報告書, 環 境保全関係資料 $4-0$-大 21 , 昭和 63 年 6 月

2) 十倉 毅; 「性能確認で合格商品を公表, 試験機関のあり 方には課題む」, 日経アーキテクチャー, 1991年11月11日 号

お知らせ

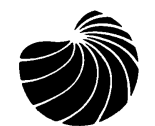

JEMECS'92

海！よみがえれ、母なる海よ。

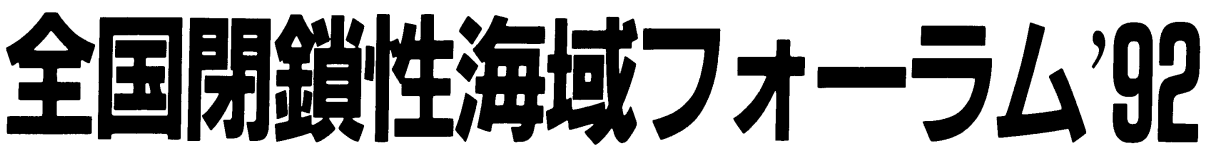

JAPAN FORUM ON THE ENVIRONMENTAL MANAGEMENT OF ENCLOSED COASTAL SEAS'92

\section{現代に生きる人アが、いま、なにをすべきか。}

○タイトル 全国閉鎖性海域フォーラム'92 JAPAN FORUM ON THE ENVIRONMENTAL MANAGEMENT OF ENCLOSED COASTAL SEAS'92

○開催期日 1992 年1 0 月1日（木）・ 2 (金)

○開催場所 長崎県大村市・大村湾内船上・ハウステンボス

○主 催 長崎県・大村市・大村湾をきれいにする会

○後援 環境庁・エメックス93評議会・N H K ・長崎新 聞社・西日本新聞社・朝日新聞社・毎日新聞 社・読売新聞社・日本経済新聞社・共同通信

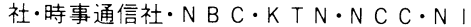
$B \cdot$ 伊万里湾環境保全対策協議会・「有明沿 岸サミット」運営協議会・鹿児島湾環境行政 連絡会議・広島湾ブルー作戦協議会・瀬戸内 海環境保全知事市長会議・兵庫県瀬戸内海環 境保全連絡会・大阪湾海水污濁対策協議会.
三河湾浄化推進協議会・伊勢湾総合対策協議 会·東京湾岸自治体公害対策会議（順不同）

○行事の概要 10 月1日（木）

・大村湾クルージング

- 前夜祭 (加山雄三トークショ一)

・ウェルカムパーティー

10 月 2 日 (金) フォーラム

- 基調講演／有吉敏彦（長崎大学教授. 長崎県公害対策審議会会長)

- 特別講演／加山雄三（俳優）

・パネルディスカッション

○参加案内 関係団体に参加申込書を配付

○実行委員長 大村市長 松本 崇

○事 務 局 T856 長崎県大村市玫島1 丁目25（大村市役所環 境衛生課内) 更0957534111代（内線 142） 